\title{
Interactive comment on "The Cloud Feedback Model Intercomparison Project (CFMIP) contribution to CMIP6" by Mark J. Webb et al.
}

Mark J. Webb et al.

mark.webb@metoffice.gov.uk

Received and published: 15 September 2016

Please refer to the attached pdf for the authors' response.

Please also note the supplement to this comment:

http://www.geosci-model-dev-discuss.net/gmd-2016-70/gmd-2016-70-AC3-

supplement.pdf

Interactive comment on Geosci. Model Dev. Discuss., doi:10.5194/gmd-2016-70, 2016. 